\title{
UK under fire over 'scrutiny' of government laboratories
}

London. The president of Britain's Royal Society has strongly criticized the government for its failure to consult more fully with the scientific community over potential changes in the way many government research laboratories are run.

The society issued a statement last week pointing to a "striking" contrast between the openness of discussions leading up to last year's white paper on science, and the conduct of a so-called 'scrutiny exercise' being used to pave the way for the privatization of a number of government laboratories.

It also warned that any new arrangements for the management of research and the ownership of research institutions that seriously weakened peer review - an implicit reference to proposals for the new Engineering and Physical Sciences Research Council (see Nature 365, 88; 1994) "would gravely damage the national capability for scientific research".

The scrutiny exercise is being carried out under the guidance of Sir Peter Levene, the head of the Cabinet Office's Efficiency Unit. It was initiated shortly before Christmas but only officially announced at the beginning of February. A team of civil servants has been taking a close look at the activities of 53 government laboratories, in particular to discover which could be effectively run by the private sector.

Included in the list are five institutes run by the Medical Research Council, including its virology, radiobiology and developmental biology units, the Science and Engineering Research Council's Rutherford Appleton and Daresbury Laboratories, and the National Physical Laboratory (Britain's equivalent of the US National Institute of Standards and Technology) currently run by the Department of Trade and Industry.

Under standard government procedures, the review team was given 90 days in which to complete a report, and a draft copy was due to be presented to the minister for science, William Waldegrave, last week. The government argues that many laboratories now run as part of the civil service would operate more efficiently if their management was handed over to the private sector

Government officials point out that privatization will not necessarily be the answer for all the laboratories being scrutinized, and that some might retain an independent, semipublic status. Indeed, one idea being considered is that the agencies that remain in the public sector should be grouped under a single Civilian Research Agency, reporting to the Office of Science and Technology (OST) and operating along the same lines as the existing Defence Research Agency.

But the Royal Society is worried that any

significant shift towards private ownership of the laboratories could damage their commitment to long-term research and undermine the government's access to independent scientific advice on important policy matters. It is also concerned at the speed of the current exercise, and the relative secrecy in which it appears to have been carried out.

"We feel that a lot of potentially very important decisions are about to be taken without adequate involvement of people outside in the scientific community," Sir Michael Atiyah, the president of the society, said last week. "We are worried that things are going very fast, and without widespread consultation or adequate scientific input."

According to Atiyah, the society is not against change, but is keen that the main

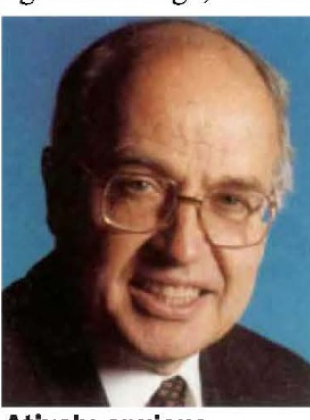

Atiyah: anxious

privatize or not.'

His views are echoed by the Institute of Professionals, Managers and Specialists (IPMS), the main union representing scientific and technical staff at the laboratories now being scrutinized, which is keen that the views of its members be heard on the fate of the institutions they work for.

"Our prime objection is that the government appears to be starting by asking which laboratories can be privatized, and then going on to discuss what to do with the others," says Valerie Ellis, deputy general secretary of the IPMS. "We welcome the idea of an efficiency scrutiny, but it should be focusing on how government research establishments can best support the objectives of the white paper."

Responding to the Royal Society's criticisms, Waldegrave said last week that, once the review is completed, "I will publish it, and will listen to the views expressed before reaching a decision." In the meantime, he said, "if people wish to make points about the scrutiny exercise, they can do so to either Bill Stewart [the government's chief scientific adviser] or myself."

OST officials say that a three-month period for public comment should allay the concerns of those who feel their points of view are being overlooked. But many scientists remain nervous.

\section{Lords panel backs ethical barriers to biotech patents}

London. A key committee of Britain's House of Lords has given its support to attempts by the European Parliament to expand the use of ethical criteria in deciding what biotechnology inventions can be patented.

But it has opposed moves to ban patents on genetic engineering techniques for altering germ-line cells. Both the European Commission and Parliament want to exclude patents on such techniques, which they describe as "contrary to the dignity of man".

Such a view is held particularly strongly in Germany. But the UK committee says that applying such a test to patents would be "very difficult to interpret", and that the questions raised should be debated in a broader medical and ethical context.

The report, published last week by the House of Lords Select Committee on the European Communities, comes as a sixyear effort in Brussels to harmonize biotechnology patent legislation between the member states of the European Union may be drawing to a close. A new draft of a revised directive was approved by the Council of Ministers in January, and will shortly go to the Parliament for a second reading.

The Lords report provides a general endorsement of the approach embodied in the current draft - in particular, its attempts to meet some of the concerns expressed by animal rights groups over patents on transgenic animals - and will boost the chances of the draft being approved before the Parliament dissolves in May.

The Lords committee says that current regulations are insufficient to ensure that biotechnological inventions are applied in a socially acceptable way and proposes an explicit list of techniques excluded from patenting, rather than general principles that would then need to be interpreted.

The report has received a relatively warm reception from some critics of animal patents. "We welcome the report, and in particular its awareness that there is a serious opposition to patents on living organisms," says Peter Stevenson, political director of Compassion in World Farming.

But Nicholas Scott-Ram of the British Biotechnology Group, says that many companies have three reasons for expressing concern about strengthening the role of ethical arguments in patent law: that it could reduce the competitiveness of the European biotechnology industry compared to that in the United States, where no such restrictions exist; that it places an unfair burden on patent officers to make ethical judgements; and that it will be difficult to ensure a "level playing field" in Europe, because different countries are likely to interpret the directive with differing degrees of vigour. 